\title{
American Society in Popular Imagination: Frank Baum's Fairy Tales
}

\author{
Makhdokht Hajighasemi \\ “...What unites people? Armies? Gold? Flags? Stories. There is nothing in this \\ world more powerful than a good story. Nothing can stop it. No enemy can \\ defeat it." Tyrion Lannister, GOT, Final Episode.
}

Stories have been present in humans' life since childhood. They facilitate the process of learning for children and help them learn about worlds other than what they live in. In such worlds, they can find relief from their fears, afflictions, and anxieties that make life more bearable for them. Bruno Bettelheim explains that while for adults grandmother's replacement by a scary wolf in "Little Red Riding Hood" is frightening, in a child's perspective it is just as scary as any other time that his or her kind and caring grandmother suddenly changed into a "figure who threatens his very sense of self" for some mistake he or she made (66). Therefore, after reading the story the child knows that although the angry grandmother can be as scary as a wolf, her mood is not permanent, and the kind and lovely granny is somewhere inside the wolf.

Unable to see any congruence between the different manifestations, the child truly experiences Grandma as two separate entities — the loving and the threatening. She is indeed Grandma and the wolf. By dividing her up, so to speak, the child can preserve his image of the good grandmother. If she changes into a wolf-well, that's certainly scary, but he need not compromise his vision of Grandma's benevolence. And in any case, as the story tells him, the wolf is a passing manifestationGrandma will return triumphant (Bettelheim 67).

Literature in the United States of America was not considered American until the 1760s. The British colonies were mostly influenced by English literature, and colonial writers did not recognize themselves as American. As larger groups of immigrants arrived in these colonies, and the new republic was searching for a united identity, American Literature began to emerge based on religious ideas. The new American society was developing rapidly. Millions of new immigrants were arriving in the US every year from different countries with different backgrounds and different hopes. Such diversity and plurality, along with significant incidents like The Civil War and the Westward movement, made the American identity vulnerable. Thus, different forms of literary genres emerged to help the American people embrace all the difficulties, find the ability to face these sudden changes, and adapt themselves to their variable living conditions while preserving their American identity. 
In this paper, I am going to study fiction as an essential form of literature that helped American society in many ways. The question is whether all fictions work alike, or do they have a different impression? As Hayden White puts it, "all stories are fiction," and whatever story one would read or hear is made but not found, so fiction has a specific role in humans' life (9). This specific role is what Robert Scholes explains in Structural Fabulation as such "[fiction] takes our worst fears and organizes them in a form charged with meaning and value" (5). He explains that cognition, the ability of fiction to help its readers to know themselves and their existential situation, and sublimation, turning our concerns into satisfying shape, are essential aspects of good fiction. These aspects - cognition and sublimationdistinguish works of fiction from one another, as some of them can successfully cover both cognition and sublimation and turn into well-known, successful pieces of literature. In contrast, some other pieces of fiction may only represent one of these aspects.

Furthermore, according to Paul L. Harris, the critical aspect of fiction is "fictional absorption," which means "to temporarily adopt a point-of-view situated inside the make-believe world rather than the real world" (342). By entering fictional absorption, the audience-both children and adults - can experience an event from a new perspective. Fictional absorption is a unique ability as in our lives; there is only one perspective available at a time for us, so seeing life through a different perspective along with ours means living more than one life. Therefore, fiction may provide us different stages of fictional absorption.

Bo Pettersson explains Samuel Levin's frame for literary communication in his book How Literary Worlds Are Shaped: A Comparative Poetics of Literary Imagination. He mentions that stories are like an "invitation to imagine," and in Pettersson's idea, this is important for children's socialization into a "culturally and emotionally joint sphere" (112).

Among different genres of children's literature, a fairy tale can be recognized as one of the most attractive and practical genres which deeply affect children's socialization. Bettelheim in The Uses of Enchantment: The Meaning and Importance of Fairy Tales mentions that a "fairy tale offers meaning on so many different levels, and enriches the child's existence in so many ways, that no one book can do justice to the multitude and diversity of the contributions such tales make to the child's life" (12). He enumerates fairy tales as an essential source of cultural adaptation for children. They are curious about many things, but they may only have limited experiences due to physical and material boundaries. Therefore, the imaginary world which fairy tales show to children is attractive because it has no boundaries. They can imagine themselves in dense forests or high mountains, speaking to wolves or fairies while lying in their bed. 
Imagination is a significant attribute for the human mind. Thomas Suddendorf explains that it is "one of the most fundamental aspects of our human mind: we can imagine things other than what is available to the senses. We can picture past, future, and entirely fictional worlds and think about them" (141). Suddendorf discusses that human's ability of imagination is not only a distinguishing cognitive attribute between humans and other animals, but it is a critical element for some other cognitive abilities as well. Pettersson mentions "literary world-making" as an example of such other cognitive abilities.

Literary world-making, as Pettersson explains, is a complicated cognitive process in which imagination plays a vital role. When humans can think about the world they live in, they are also able to think about worlds different from that, and this means world-making. Pettersson claims that imagination is a significant key to literary world-making. He categorizes imagination into two categories: individual and popular, and he puts the literary imagination under the latter category. He emphasizes that popular imagination acts as a "shared frame of mind" for humankind, and it is essential for shaping nations and their cultures (21). As Pettersson quotes Michael Tomasello, imagination helps humans to learn about others and develop empathy, not just from them, but through them (25). In other words, through imagination, anyone can learn about other human beings not just by observing their lives, but by imagining oneself in their position, or as Tomasello puts it, "they can imagine themselves 'in mental shoes' of some other person" (6).

Pettersson argues that for literary world-making, we need to have some modes of literature (oral, visual, and written), or some literary themes (challenge, perception, relation). Then, by imaginative use of mimesis, we can make changes in or to these modes and themes to make a new literary world. This process of literary worldmaking, as Nelson Goodman claims, is remaking because the author always builds the new world based on the world he or she already knows (6). Pettersson also mentions that literary world-making is always based on the real world we live in; therefore, social and historical events occurring in the real-world can influence literary world-making.

Scholes in Structural Fabulation explains that different literary genres represent a connection to their development period. For example, in the early nineteenthcentury novel was a recording of changes in history, and it was considered as a "source of political understanding" (Whitebrook 32). Later, technological developments contributed to the concept of future as a radically different condition than the present time, and as its result, fantasy and structural fabulation came into existence. Oliver Conolly and Bashshar Haydar explain this in "Literature, Politics, And Character" as such: "certain political environments give rise to certain types 
of literature, and that those political backgrounds thereby explain certain aspects of literary phenomena" (87).

In Scholes's opinion, some of the most effective and valuable examples of structural fabulations "are direct projections of the present, which provide concrete realizations of current trends in our political and social situation" (70). Taking these in mind; I want to study L. Frank Baum's The Wonderful Wizard of $\mathrm{Oz}$ as a well-known American fairy tale to investigate the role of popular imagination in the literary world-making of this author. Grounding my analysis in the ideas of Bo Pettersson and Robert Scholes, I investigate the relationship between the imaginary worlds which Baum's fairy tale offers to the readers and the world Americans experienced at the time. By exploring the literary world of this tale, I want to explain why it could become a twentieth-century landmark in children's literature in the United States. For a better understanding, I would compare The Wonderful Wizard of $\mathrm{Oz}$ with another fairy tale book of Frank Baum, American Fairy Tales. I would like to investigate to what extent they are different and how Pettersson and Scholes's ideas can explain why one of them is a huge success while the other is not even well-known.

Lyman Frank Baum was an American writer who is known for his books about the land of Oz. Published in 1900, it was an enormous success for him, and he continued writing a series of books under this title. In Baum's idea, as he mentions in his introduction for The Wonderful Wizard of $\mathrm{Oz}$, new generations need new fairytales with new themes that can serve current society's interests, that he names "modern fairy tales." It is a unique example of an American fairy tale that is different from traditional European tales in many aspects, mainly reflecting American values in its plot.

America was an ideal destination for many immigrants during the seventeenth and eighteenth centuries because of "the chance for individual freedom, equality of opportunity, and material wealth" (Datesman, Maryanne Kearny., et al. 32). These benefits were available to those who were ready to pay the price of self-reliance, competition, and hard work. These values have been pillars of the unique culture of the United States from the beginning until today. Although Baum describes his book as a means of pleasure for children and not a source for moral lessons, his fairy tale contains different social and historical moral-like messages.

The story is about a girl named Dorothy, who lives on a farm with her aunt and her uncle. She is caught by a cyclone which dislocates her, her house, and her dog, Toto, into Munchkin county of the imaginary land of Oz. The house falls over the Wicked Witch of the East and kills her and makes all the residents of Munchkin very 
happy. Dorothy wants to go back home, and The Good Witch of the North explains to her that her only chance is to ask the great and powerful Wizard of $\mathrm{Oz}$ to help her. She gives Dorothy the silver shoes of the Wicked Witch of the East and kisses her on her forehead as magical protection on her journey to Emerald City, where she could meet Oz. On her way to Emerald City, she finds some friends, a Scarecrow who was looking for a way to earn a brain for himself, a Tin Woodman who was wishing to have a heart for himself, and Cowardly Lion who wanted courage. They decide to go with Dorothy to the Emerald City and ask Oz to help them grant their wishes. After different adventures, they arrive at the capital. Oz represents himself in a different form for each of them and tells them how to reach what they want; they need to kill the Wicked Witch of the West, who is ruling over the Winkie county.

The Wicked Witch of the West tries her best to stop the travelers on their way. She finally manages to break the group apart and enslaves Dorothy. One day, when the Wicked Witch of the West wanted to steal Dorothy's silver shoes, Dorothy dashed a pot of water over the Wicked Witch of the West and melted her away. Then she managed to rescue her friends, and they returned to Emerald City to earn their prizes from $\mathrm{Oz}$. There, they learn that $\mathrm{Oz}$ is just an ordinary man and not a wizard. Oz sews a new head full of bran on the body of the Scarecrow instead of a brain, puts a silk heart stuffed with sawdust in the Tin Woodsman's chest, and gives a magical courage potion to the Cowardly Lion. After meeting Dorothy, $\mathrm{Oz}$ misses his home and plans his return. He flies away with his Balloon to Omaha and leaves Dorothy behind. So, she goes to see Glinda, the Good Witch of the South, asking for her help. There she learns that her silver shoes, which she had them from the very beginning, can take her anywhere she wishes to go. With the help of her magic shoes, Dorothy and Toto go back home to Kansas.

As I mentioned above, this story is an excellent example of presenting social concepts and values like self-reliance, hard work, freedom, self-discipline, and competition in the form of children's tales. At the beginning of the story, Dorothy is not self-reliant. She is frightened because she cannot find her way back home. Still, Dorothy does not consider finding her way back home on her own. She immediately asks around for the solution, which shows her lack of self-reliance and self-confidence. During her journey, whenever there is a danger around or problems to solve, her male companions step out to fix the situation. She is defiantly different from usual passive fairy tale heroines, but still, her actions emphasize that problem-solving is not an essential characteristic for women. Even though she is the actual human being within her group, with an actual brain and actual heart, she always fails to demonstrate her abilities.

On the one hand, Baum tries to explain that magic is not the answer to every problem. In order to achieve a mindful brain, a kind, and caring heart, and 
desirable courage, one should take responsibility and work hard, and then what is needed would be found inside, just like the concept of the self-made man. On the other hand, Baum's solution for Dorothy's problem, which could not be solved by her efforts, is magic at the end. This part can be seen as believing in miracles and hoping to achieve the desired result by relying on forces beyond the human effort, which is also a popular part of the American culture.

Dorothy's journey to find a way back home contains familiar elements of American culture and history. The book is written almost a decade after the official closure of the frontier. Therefore, tracing elements of the myth of the frontier in this text is not surprising. The Witch of the West is wicked, and to achieve what was promised to Dorothy-like the concept of Promised Land or Manifest Destiny-she needed to conquer the west, and by doing that, she could go back home and bring a better life to the residents of that land. The protecting kiss from the Good Witch of the North can relate to the concept of "God is on our side," which is a crucial element in American Identity. This kiss saved Dorothy in many situations while her other companions did not have such an advantage. In contemporary history, Americans justified many of their actions, like regime change wars or military interventions in the Middle East, according to the ideology of "God is on our side." For example, George W. Bush justified his invasion of Iraq or his foreign policies toward the Palestinian-Israeli conflict by mentioning that "God told me to end the tyranny in Iraq" or "I am driven with a mission from God" (MacAskill).

Denouncing slavery is also a prominent theme in the plot as the wicked witches had enslaved their citizens while good witches did not. The story was written almost four decades after ratifying the Thirteenth Amendment, but American society was still struggling with different issues related to slavery. All these examples are supporting Scholes's idea that valuable examples of fiction can provide readers with projections of their cultural and political trends.

In his literary world-making, by using popular imagination, Baum built his imaginary world as a close projection of American society at his time. He elaborated essential American values through his plot, which made his fiction a valuable piece because it covers both the sublimation and cognition aspects of good fiction. Sublimation as helping its readers understand rapid social and cultural changes in the western territories, and cognition as it gives them a core understanding about American identity and values and explains to them how they can achieve them.

Challenge is a major theme of the story. Dorothy had to find a way back home, and she and her friends were asked to kill the Wicked Witch of the West. The perception theme is present too. The Scarecrow, the Tin Woodman, and the Cowardly Lion had to figure out their abilities through hard work and self-reliance, and Dorothy had to know her belongings better to solve her problem and go back 
home. Moreover, the relation theme is also present in this tale as friendship among Dorothy, Toto, Scarecrow, Tin Woodman, and Cowardly Lion leads the narrative. So, this story represents Pettersson's literary world-making in every aspect.

Besides this triumphant fairy tale, Baum wrote a collection of short fairy tales under the name of American Fairy Tales. Unlike The Wonderful Wizard of $O z$, American Fairy Tales is unknown, and it could never get the same attention as the previous book did.

Magic has a less critical role in American Fairy Tales, and protagonists can solve their problems by themselves through thinking and self-reliance. An essential difference between the tales of this collection and The Wonderful Wizard of $\mathrm{Oz}$ is that they are more like moral lessons. For example, in one of the stories named "The Box of Robbers," a girl named Martha happens to stay home alone, and while wandering around the pantry, she finds a chest that belonged to her uncle. She was told before that, as uncle Walter requested, this chest should remain unopen until he comes back, but because of her curiosity, she tries to open it. Finally, when she succeeds in opening the chest, three Italian Bandits come out of it. They try to rob Martha's house, but she figures out a solution to put them back in the chest and lock them up again.

In another story named "The Girl Who Owned A Bear," Jane, the girl, receives a book from one of her father's former employees who wanted to take revenge on Jane's father. Any animal, which was shown in the illustrations of that book could come to life and while Jane was reading the book, an angry bear jumped off the pages to eat Jane, but she quickly thought and found out a solution and saved herself.

Imagination is present in these tales, and they contain moral lessons, but they only engage the individual level of imagination. The literary worlds they build are not separated from the real world, and their messages are rather personal than community-oriented. They do not represent any connection to social or historical events at their time, so from a moral aspect, they have nothing to share with their readers. They may cover the sublimation aspect of good fiction, but they can never cover the cognition part.

To sum up, The Wonderful Wizard of $\mathrm{Oz}$ as a successful American fairy tale represents both aspects of good fiction. Baum made his literary world by using popular imagination of American society and represented different trends of his era in this book, which can be considered as an essential factor for his success. Using challenges, perception, and relation themes at the same time made the literary world of this story even more enjoyable. As a famous fairy tale, both in publication and later adaptations, it is a perfect example of a close relationship between the imaginary world and the real world that it reflects. Such a relationship can help readers connect themselves to the make-believe world easier and help them find a 
better relief as they can project themselves into an imaginary world surrounded by the same problems as they face in their real lives.

\section{WORKS CITED}

Baum, Lyman Frank. American Fairy Tales. George M. Hill Company, 1901, https://freeclassicebooks.com/L. Frank Baum/American Fairy Tales.pdf.

Baum, Lyman Frank. The Wonderful Wizard of Oz. Global Grey, 2018, https:// www.globalgreyebooks.com/wonderful-wizard-of-oz-ebook.html.

Bettelheim, Bruno. The Uses of Enchantment: The Meaning and Importance of Fairy Tales. Vintage Books, 2010.

Conolly, Oliver, and Bashshar Haydar. "Literature, Politics, and Character." Philosophy and Literature, vol. 32, no. 1, Apr. 2008, pp. 87-101. Project Muse https://doi.org/10.1353/phl.0.0011

Datesman, Maryanne Kearny., et al. American Ways: An Introduction to American Culture. Fourth ed., Pearson Education, 2014.

Goodman, Nelson. Ways of Worldmaking. Hackett Publishing Company, 1978.

Harris, Paul L. "Fictional Absorption: Emotional Responses to Make-Believe." Intersubjective Communication and Emotion in Early Ontogeny, ed. Bråten Stein, Cambridge UP, 1998, 336-353.

Horton, John, et al. "Taking the Narrative Turn." Literature and the Political Imagination, Routledge, 1996, 32-52.

MacAskill, Ewen. "George Bush: 'God Told Me to End the Tyranny in Iraq'." The Guardian, Guardian News and Media, 7 Oct. 2005, www.theguardian.com/ world/2005/oct/07/iraq.usa. Accessed 16 April 2019

Scholes, Robert E. Structural Fabulation: An Essay on Fiction of the Future. UMI, 1995.

Suddendorf, Thomas. The Gap: The Science of What Separates Us from Other Animals. Basic Books, 2013.

Tomasello, Michael. The Cultural Origins of Human Cognition. Harvard UP, 1999.

White, Hayden. Figural Realism: Studies in the Mimesis Effect. The Johns Hopkins UP, 1999. 